\title{
Certification of açaí agroforestry increases the conservation potential of the Amazonian tree flora
}

\author{
Gabriel Damasco (1) - Mandy Anhalt • Ricardo O. Perdiz • Florian Wittmann • \\ Rafael L. de Assis · Jochen Schöngart • Maria T. F. Piedade - Christine D. Bacon • \\ Alexandre Antonelli $\cdot$ Paul V. A. Fine
}

Received: 1 June 2021 / Accepted: 20 December 2021/Published online: 8 January 2022

(C) The Author(s) 2022

\begin{abstract}
The harvesting of açaí berries (palm fruits from the genus Euterpe) in Amazonia has increased over the last 20 years due to a high local and global market demand and triggered by their widely acclaimed health benefits as a 'superfood'. Although
\end{abstract}

Supplementary Information The online version contains supplementary material available at https://doi.org/10.1007/ s10457-021-00727-2.

G. Damasco $(\varangle) \cdot$ C. D. Bacon · A. Antonelli

Department of Biological and Environmental Sciences, University of Gothenburg, Göteborg, Sweden

e-mail: gabriel.damasco@ufrn.br;

gabrielfloresta@gmail.com

G. Damasco - C. D. Bacon · A. Antonelli

Gothenburg Global Biodiversity Centre, Göteborg,

Sweden

G. Damasco

Department of Botany and Zoology, Universidade Federal

Do Rio Grande Do Norte, Natal, Brazil

M. Anhalt

Global Compliance Department, Sambazon, Inc,

San Diego, CA, USA

R. O. Perdiz · F. Wittmann · J. Schöngart ·

M. T. F. Piedade

Instituto Nacional de Pesquisas da Amazônia, Manaus,

AM, Brazil

R. O. Perdiz

Luz da Floresta, Rua Xiriana, 311, Aparecida, Boa Vista, RR, Brazil such increase represents a financial boom for local communities, unregulated extraction in Amazonia risks negative environmental effects including biodiversity loss through açai intensification and deforestation. Alternatively, the introduction of certified sustainable agroforestry production programs of açaí has been strategically applied to reduce the exploitation of Amazonian forests. Local açaí producers are

\author{
F. Wittmann \\ Department of Wetland Ecology, Institute for Geography \\ and Geoecology, Karlsruhe Institute for Technology, \\ Karlsruhe, Brazil \\ R. L. de Assis \\ Natural History Museum, University of Oslo, Oslo, \\ Norway
}

\section{A. Antonelli \\ Royal Botanic Gardens Kew, Richmond, UK}

\author{
A. Antonelli \\ Department of Plant Sciences, University of Oxford, \\ Oxford, UK \\ P. V. A. Fine \\ Department of Integrative Biology and Jepson and \\ University Herbaria, University of California, Berkeley, \\ CA 94720-3140, USA
}


required to follow principles of defined sustainable management practices, environmental guidelines, and social behaviors, paying specific attention to fair trade and human rights. In this study we investigate whether sustainable agroforestry and certification effectively promotes biodiversity conservation in Amazonia. To address this question, we conducted a forestry inventory in two hectares of long-term certified açai harvesting areas to gain further knowledge on the plant diversity and forest structure in açaí managed forests and to understand the contribution of certification towards sustainable forest management. On average, we found that certified managed forests harbor 50\% more tree species than non-certified açaí groves. Trees in certified areas also have significantly higher mean basal area, meaning larger and hence older individuals are more likely to be protected. Certified harvesting sites also harbor dense populations of threatened species as classified by the International Union for Conservation of Nature (e.g. Virola surinamensis, classified as 'endangered'). Besides increasing the knowledge of plant diversity in açaí managed areas, we present baseline information for monitoring the impact of harvesting activities in natural ecosystems in Amazonia.

Keywords Euterpe - Açaí management · Flooded forests $\cdot$ Biodiversity conservation $\cdot$ Amazonia

\section{Introduction}

The expansion of the açaí (Euterpe sp.) fruit economy in Amazonia has not only supplied a growing worldwide demand but has also helped to establish new frontiers of commercialization. The market boom for açaí berries has motivated producers to expand açaí agroforestry into pristine and unmanaged forests, especially in eastern Amazonia (Brondizio 2008). Although açaí agroforestry does not involve outright deforestation, intensive management practices gradually replace native tree species by thinning and/or with dense açaí palm plantings in the understory to enhance productivity (Homma et al. 2006; Freitas et al. 2015). Besides, management practices typically include the gradual removal of other native trees near açaí palms, promoting canopy opening, and reducing overall competition for light and nutrients. This unregulated management leads to an erosion of the regional flora and can cause considerable changes in the vegetation structure and ecosystem functioning of Amazonian forests (Freitas et al. 2015).

Given the rampant habitat loss and reduction in forest biodiversity due to recent açaí expansion (Freitas et al. 2015; Campbell et al. 2018; Bezerra et al. 2020) and the vulnerability of açaí palm forests to climate change (Tregidgo et al. 2020), an innovative strategy for sustainable agroforestry management is urgently needed to prevent biodiversity loss and deforestation. Currently, the açaí market in Brazil lacks a clear and uniform policy that regulates the promotion of biodiversity conservation in harvesting areas. Yet, due to high demand for organic and sustainable products, açaí food companies (especially from North America and Europe) have invested in certification programs that inform consumers about whether the product is in accordance with health, ecosystem conservation, and human rights (e.g. USDA Organic, Regenerative Organic, Biodynamic, Fair trade and Fair for Life).

Certified açaí agroforestry may provide many environmental and social benefits. It can improve livelihoods for local residents, promote conservation of intact forests that harbor high biodiversity, and prevent unregulated deforestation that, in turn, exacerbates global climate change (Weinstein and Moegenburg 2004; Lovejoy and Nobre 2018; Brando et al. 2020). Certifiers have a diverse array of objectives and standards, meaning that they do not necessarily address all facets of sustainability (e.g., Perrigo et al. 2020), but most define criteria relating to environmental and social outcomes (World Conservation Monitoring Centre 2011).

In tropical countries, such as Brazil, third party certification could play an important role considering the negative effects of a growing commodity production (Gibbs et al. 2010), and the need for governmental capacity and resources to regulate agriculture effectively (Barrett et al. 2001). "Fair for Life" is a Fair Trade certification standard developed and managed by EcoCert Group. Sambazon Inc., has been certified to the first standard developed by Ecocert since 2008 and was the first company to have Fair Trade certified açaí. "Fair for Life" is composed by the "Fair Trade and Responsible supply-chain" certification and the "For Life Standard" for "Corporate Social Responsibility" certification. Both have environmental 
requirements at the local and corporate levels as a corner stone of the certification scheme. For an açaí product to become Fair for Life certified, local producers and harvesters must follow standards regarding the respect of human rights and fair working conditions, promotion of biodiversity and sustainable agroforestry practices, and have a positive impact on local communities (EcoCert Group 2020). Each operation is audited annually by the Ecocert group to ensure the companies are following these rules.

With the increasing public, governmental, and corporate interest in sustainable consumption (Govindan 2018; Matharu et al. 2020), it is important to understand the contribution of sustainable agroforestry and certification in promoting biodiversity conservation. Here, we determine tree species composition and forest structure of fair for life certified açaí harvesting areas in eastern Amazonia and compare our results with (1) non-certified açaí plantations and (2) transects in intact Amazonian flooded forests. Our aim is to explore the potential contribution of açaí agroforestry and certification to halting deforestation and species loss in Amazonian forests. We predict that certified harvesting areas harbor a richer tree community and a less impacted forest than non-certified sites. Additionally, this study establishes research plots in areas never sampled before and used sampling methodologies compatible with protocols used by researchers worldwide. Thus, our results could potentially contribute to larger-scale biodiversity studies.

\section{Methods}

Study sites

The certified harvesting areas sampled in our study are located in Eastern Amazonia. Sampling sites were placed on private lands situated along tributary water channels of the Amazonas River. The primary habitat in this region is seasonally flooded forest (known in Amazonia as várzea forests) and the açaí palm (Euterpe oleracea Mart.) is a dominant and widespread palm species native to these habitats. Here, we conducted tree-plot inventories that encompassed the spectrum of açaí management varying from an almost complete replacement of trees with açaí to no tree removal or destructive interference. We sampled harvesting lands that have been certified in the last
12 years through the partnership between Sambazon Inc. (https://www.sambazon.com/) and ECOCERT Group (https://www.ecocert.com) as part of the "Fair for Life" fair trade certification. This certification is based on principle that threatened or endangered species and habitats are protected and natural ecosystems are not destroyed. More information about requirements and criteria that are expected to be met under the Fair for Life certification is available in the Table S1.

This study comprises three main distinct sets of inventory plots: (1) 20 plots of certified açaí managed forests established along in eastern Amazonia along the Mariazinho River in Breves County, Pará State, Brazil (S 00 51.902' W 51 04.961') and Gurupá County, Pará State, along the Mararú River (S $1^{\circ} 11.167^{\prime} \mathrm{W} 51^{\circ} 32.732^{\prime}$ ) and in the Bailique Archipelago region, Amapá State ( $\mathrm{N}^{\circ} 28^{\prime} 49.77^{\prime \prime}$ and W $\left.50^{\circ} 24^{\prime} 39.74^{\prime \prime}\right)$; 2) 24 plots of non-certified açaí groves published by Freitas et al. (2015) named in their publication as "managed sites"; (3) total of 50 plots from intact and unmanaged flooded forests sites (named here as control plots). 38 control plots were made available by the PELD-MAUA research group (https://peld-maua.inpa.gov.br). This research network manages a large dataset of forestry inventories held across flooded forests in the Amazon Basin (Fig. 1, Table S3). In addition, 12 control plots were published by Freitas et al. (2015), named in their publication as "unmanaged control sites" (Fig. 1, Table S3).

\section{Sampling}

For certified harvesting areas, the 20 plots were 0.1 ha in size each $(20 \mathrm{~m} \times 50 \mathrm{~m})$, representing a cumulative sampling area of 2 hectares. Using maps and GIS resources, the 0.1 ha-plots were randomly selected a priori and established within each of the twenty certified harvesting lands visited. All woody plant species with a diameter at the breast height (DBH) above $10 \mathrm{~cm}$ (considered here as 'trees') were measured, collected, and identified to species when possible. The fieldwork was comprised by two expeditions held in August 2019 and January 2020. Voucher specimens for each tree species have been deposited at the INPA (Instituto Nacional de Pesquisas da Amazônia) Herbarium in Manaus, Brazil. Taxonomic classification followed APG IV (http://www. 

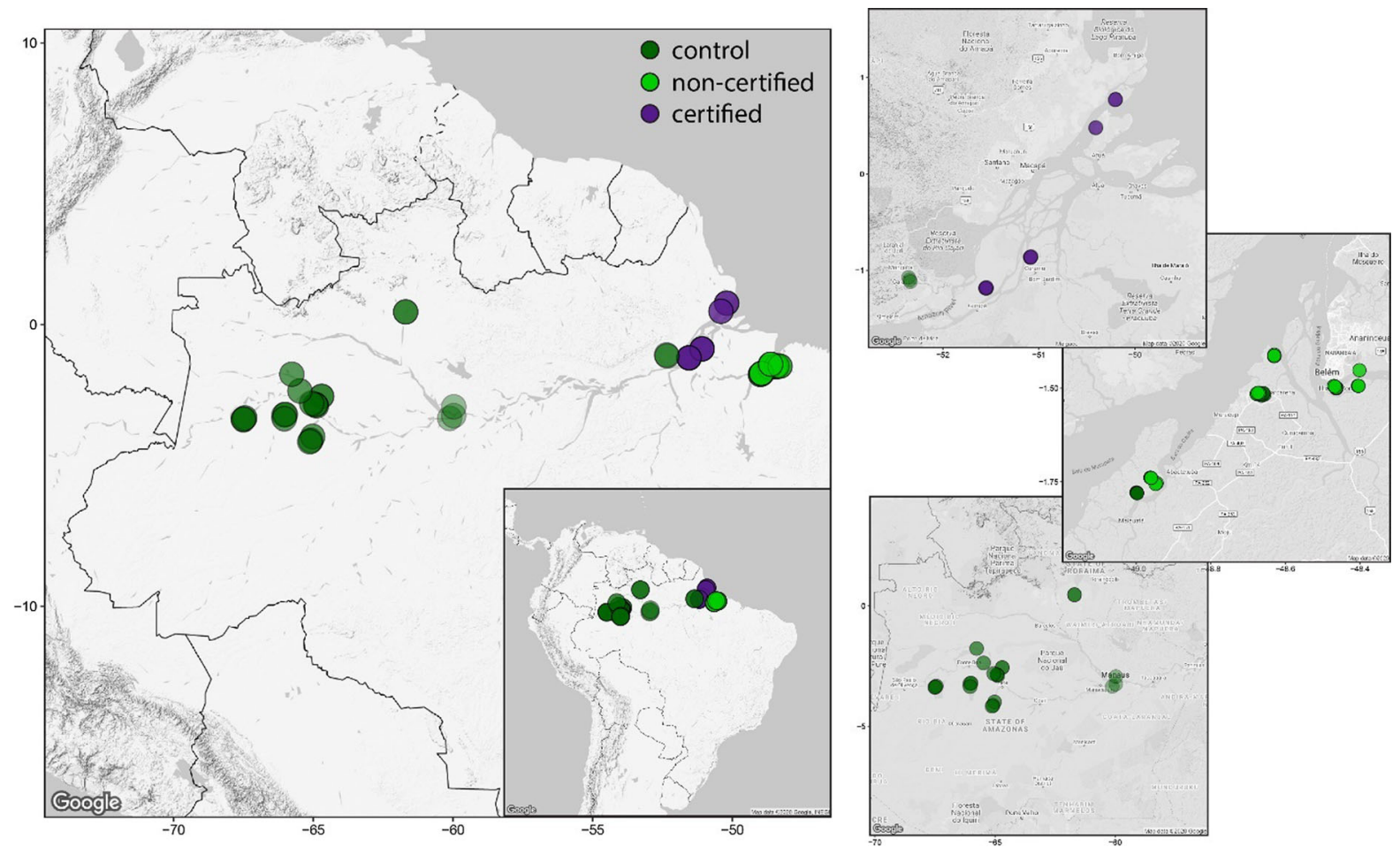

Fig. 1 Geographical location of 94 study cites located across flooded forests in the Brazilian Amazonia. Control plots represent intact flooded forests with no influence of açaí management practices. 38 control plots were made available by the PELD-MAUA data network (https://peld-maua.inpa.gov. br) and 12 control plots are available in Freitas et al. (2015).

mobot.org) and species names were checked against the Plants of the World online (POWO, http://www. plantsoftheworldonline.org/). For details of sampling methods of non-certified harvesting areas and control plots (Table S3), please see Freitas et al. (2015) methods section and the PELD-MAUA research group data repository (https://peld-maua.inpa.gov.br).

\section{Analysis}

We calculated diversity (species richness, Fisher diversity index) and forest structure (basal area, açaí clump density) parameters for the certified, noncertified, and control data sets. Diversity and basal area metrics are calculated accordingly to scientific literature on Amazonian floodplains (e.g., Assis et al. $2015,2019)$. Fisher's $\alpha$ diversity index was determined according to the formula $S=\alpha \times \ln (1+n / \alpha)$ where $S$ is the number of species, $n$ is the number of individuals, and $\alpha$ is Fisher's alpha. Tree basal area
Non-certified plots are available in Freitas et al. (2015) and comprise of forests managed for açaí production by riverine smallholders that are free of certification standards. Certified plots are made available by this study and represent forests managed for açaí production that has been under the Fair for Life certification since 2008

was calculated based on the formula $g=\left(\pi \times D B H^{2}\right) / 4$ where $g$ is basal area in $\mathrm{m}^{2}$. To compare the diversity and forest structure of certified, non-certified, and control plots we used the non-parametric Wilcoxon test as variables were not normally distributed. We then performed a linear model to test the association between species richness/basal area and the açaí density among certified, non-certified, and control plots. All statistical analyses were performed in R 3.4.1 (R Core Team 2020) using the package "vegan" (Oksanen et al. 2020).

We acknowledge that the control, certified and noncertified plots are not evenly distributed across the geographic space and the majority of certified and non-certified plots are skewed to Eastern Amazonia. Therefore, results on tree diversity and forest structure could also reflect responses to geographic variation, including the climatic difference, disturbance history and the effects associated with the spatial distance across the region. Despite the potential spatial bias, 
there is no known evidence for local tree diversity, long-term disturbance history or climate in flooded várzea forests to be remarkably different between certified plots vs. non-certified plot sites. In Eastern Amazonia, Amapá and Pará States are two of the most expressive areas in terms of açaí production and marketing in Brazil and açaí managed forests are frequently found across várzea forests in this region.

To disentangle the effects of certification, climatic differences, and geographic distance among plots, we performed a decomposition of the explained variation using distance-based redundancy analysis (db-RDA) available in the R package "vegan" (Oksanen et al. 2020). Temperature and precipitation data were extracted from the Worldclim database (www. worldclim.org/data) and the variation of temperature and precipitation variables were reduced based on principal component analysis. Linear distances among all plots were calculated using the R package "geosphere" (Karney 2013).

\section{Results}

Species composition and structure of certified açaí harvesting forests

In total, we sampled 131 tree species at the certified sites represented by 36 botanical families and 109 genera (Table S2). The number of families and tree species accounted for $50 \%$ and $18 \%$ of the MAUA database (control group) that includes floristic data from forests across Amazonia. On average, certified açaí managed forests harbored a greater number of tree species than non-certified açaí (Fig. 2a). The number of tree species was significantly higher $(P=0.00634)$ in certified harvesting areas and 50\% higher than noncertified groves, on average (Table 1). In contrast, both certified and non-certified forests are less diverse in terms of species richness in comparison to the control plots $\left(P=1.0087 \mathrm{e}^{-9}, P=1.654 \mathrm{e}^{-8}\right.$ for both pairwise Wilcoxon tests).

In terms of forest structure, certified açaí forests had trees with greater values of basal area per hectare $\left(P=0.01567 \mathrm{e}^{-6}\right)$, Fig. 2). On average, basal area values were ca. $150 \%$ higher in certified forests (Table 1). The largest individual trees were from the species Ceiba pentandra (L.) Gaertn., Spondias monbin L. and Mora paraensis (Ducke) Ducke with
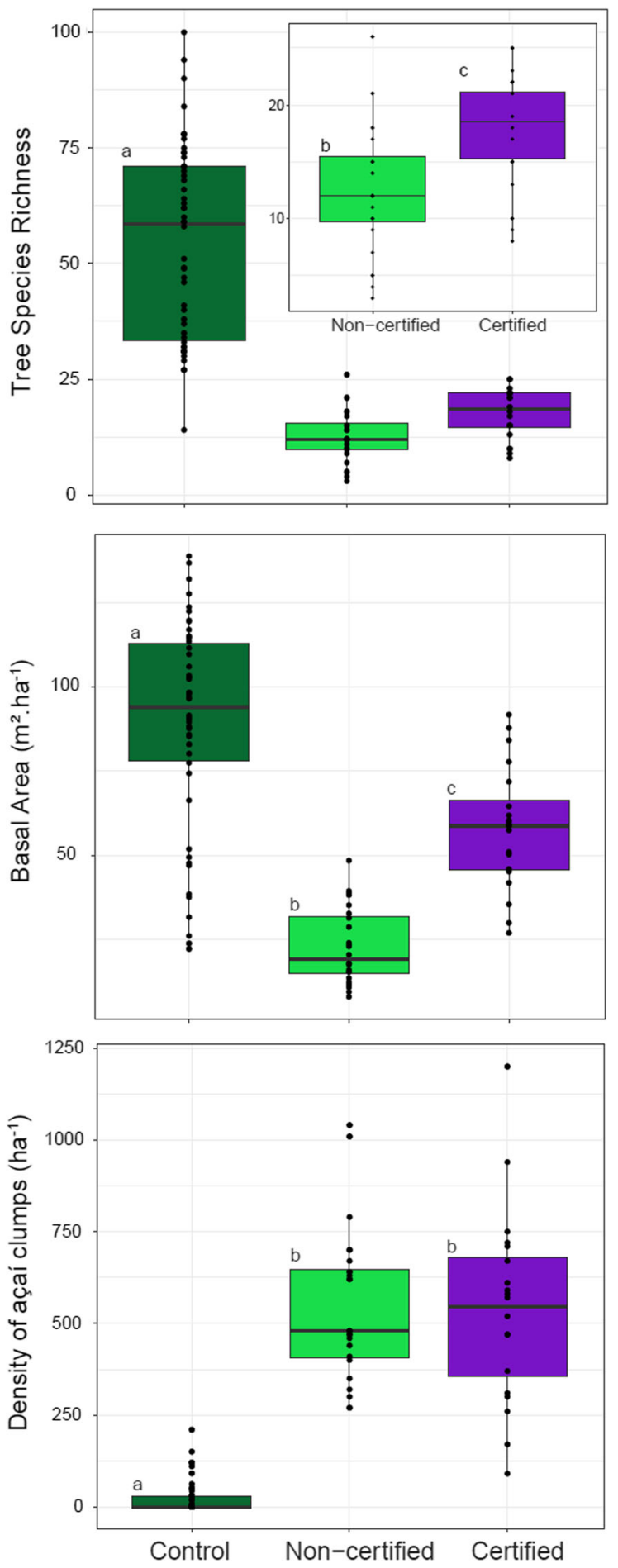

diameters over $120 \mathrm{~cm}$ at the breast height (DBH). All certified studied plots obtained basal area values (26.9-91.7 $\mathrm{m}^{2} . \mathrm{ha}^{-1}$ ) within the range of variation comparable to intact forests (Table 1, Fig. 2). 
4 Fig. 2 Comparisons of tree species richness, basal area, and density of açaí clumps among certified, non-certified and control plots. Boxplots above shows the distribution of the data based on the median, first and third quartile, and minimum and maximum values. Letters on the left upper corner of each box represent the result of the pairwise and non-parametric Wilcoxon test. Distinct letters indicate a significant statistical difference among groups ( $p$-values are displayed in the main text of the manuscript)

Although species richness and basal area significantly differed between certified and non-certified plots, we found no significant difference between açaí abundance when both groups are compared (Fig. 2c, $P=0.8781)$. Therefore, certified areas were richer in terms of floristic composition, had a larger forest stature (higher basal area), and possessed comparable açaí density as non-certified forests.

Relationship between richness and açaí clump
density

We found a negative relationship between the density of açaí clumps and the species richness in açaí managed forests. The higher the açaí clump density is, the lower the diversity of tree species is in both certified and non-certified harvesting areas (Fig. 3). However, certified data showed a trend with a lower slope than non-certified data (slope $_{\text {certified }}=$ $-0.01, \mathrm{R}_{\text {certified }}^{2}=0.215 ;$ slope $_{\text {non-certified }}=-22.75$, $\mathrm{R}_{\text {non-certified }}^{2}=0.677$, respectively). Even in sites with a high density of açaí clumps, certified harvesting areas tend to have a more species rich composition and a larger tree basal area than non-certified açaí groves (Table 1, Fig. 3).

The relationship between the density of açaí clumps and the species richness is still significant when the explained variation is partitioned using the db-RDA analysis. Despite the climatic distinction over a large spatial range among the studied plots (Figure S1A), we did not find supportive evidence that species richness could be associated with the climatic variation over the space. We did find a partial association between richness and the spatial distances among the plots (Figure S1B), possibly due to the overwhelming number of control plots from the PELD-MAUA research network that are located in western Amazonia. Even though the spatial correlation is present, the number of species among certified, non-certified, and

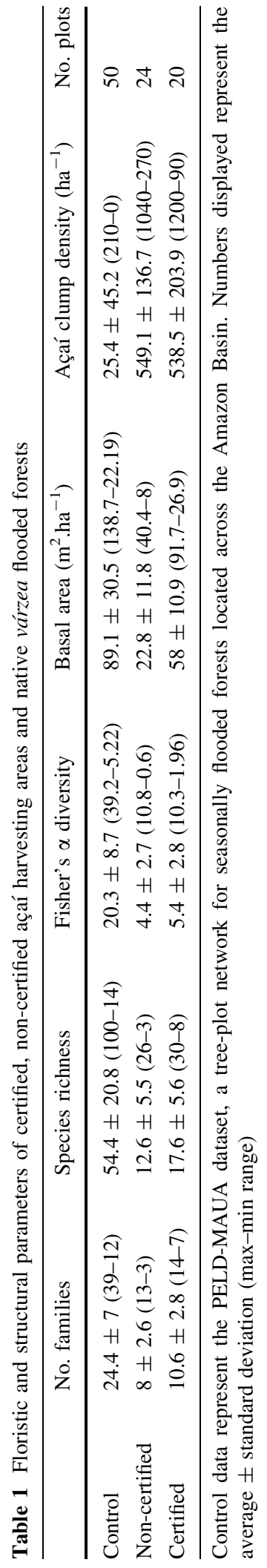


Fig. 3 Linear correlation between tree species richness and basal area against density of açaí clumps in certified and noncertified plots. Both graphs show a negative relationship and as the density of açaí clumps increases in managed forests the number of species and the basal area of both certified and noncertified tend to decrease. However, the decrease in species richness at certified plots is less pronounced than non-certified plots (slope and $\mathrm{R}^{2}$ values are displayed in the main text of the manuscript)

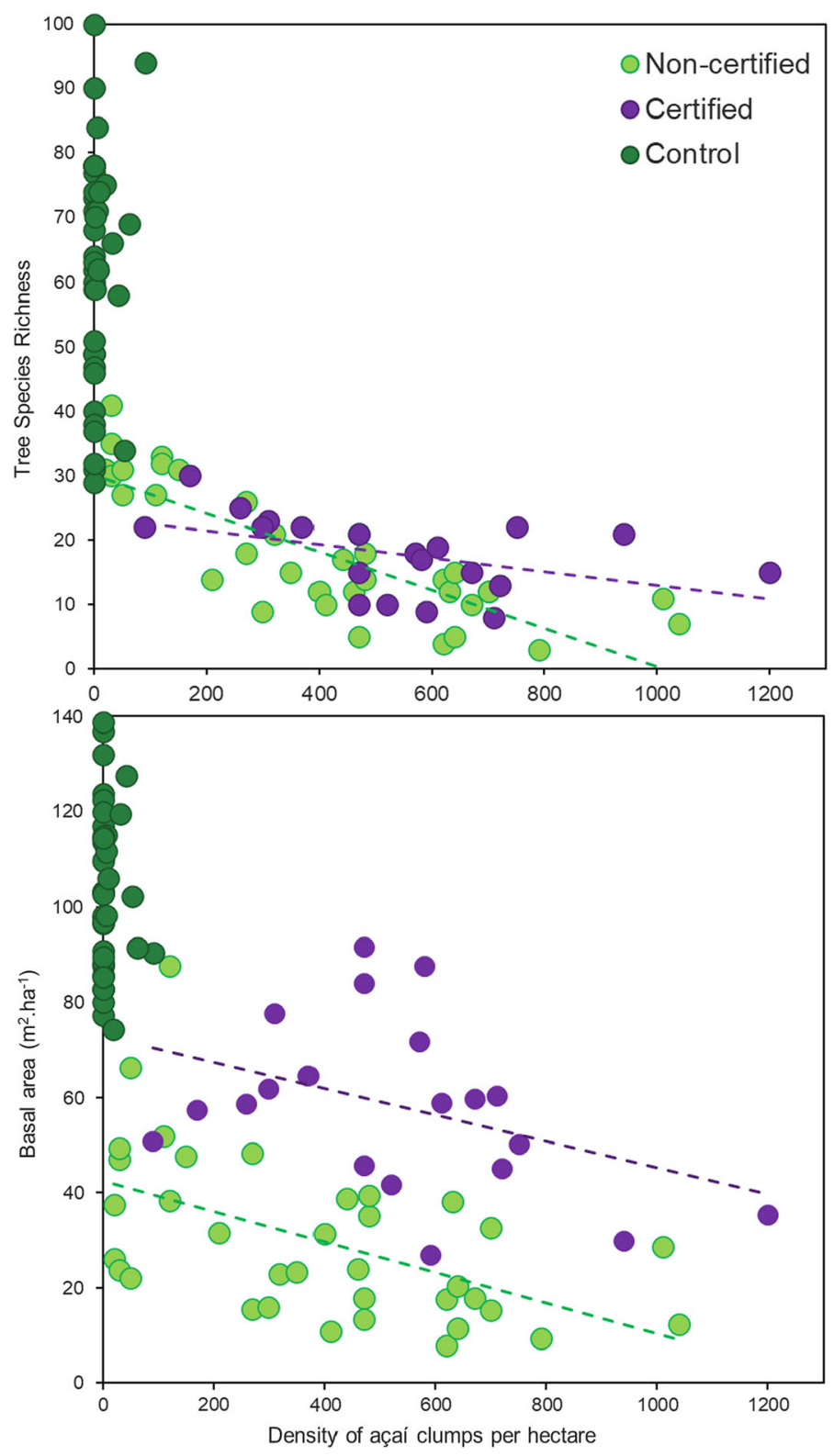

control plots was still significantly explained by the density of açaí clumps in the studied managed forests (Figure S1B).

Flora of certified açaí managed forests

The most dominant botanical families found in the certified plots were Fabaceae (27 spp., 303 individuals), followed by Myristicaceae (2 spp., 95 individuals), Malvaceae (9 spp., 78 individuals), Anacardiaceae (2 spp., 64 individuals), and
Euphorbiaceae (4 spp. 49 individuals). These families together account for more than 50\% of the total number of tree species sampled in certified managed sites (Table S2). Virola surinamensis, the most representative tree species, and Minquartia guianensis are registered in the IUCN red list as endangered taxa. Some popular agroforestry species, including nonnatives, were also found amid certified forests (e.g. Mangifera indica, Theobroma cacao, Spondias mombin, Musa spp.). 


\section{Discussion}

Can certification of açaí agroforestry support conservation of the Amazonian flora?

Despite the lack of a temporal monitoring assessment in our experimental setup, we identify that managed sites after 12 years of certification have a higher species richness than non-certified groves. Additionally, the forest structure of certified sites is considerably more intact compared to non-certified areas. Even though açaí abundance is similar across the different sites and the potential for fruit productivity may be then equivalent, the basal area of native trees was much higher in certified than non-certified managed areas. We presume that certified producers preferentially take conservative and lower impact measures regardless of the prior state of conservation of managed sites. Therefore, even if the certified plots included in our study had a better conservation status (e.g., with higher species richness and biomass) before certification was implemented, certified and trained producers acted differently than the intense and uncontrolled management usually applied by noncertified producers (as in Freitas et al. 2015). In addition, regardless of a possible geographical bias in the sampling design, certification and best management practices on their own appear to have a noteworthy effect on protecting the tree diversity and the forest structure of açaí harvesting forests. Our comparisons allow us to conclude that there is a high conservation potential of certified açaí agroforestry to reduce the degradation of the Amazonian tree flora.

During the certification training, producers are informed about the role of biodiversity and respective ecosystem services. In addition, harvesters are prohibited from engaging in illegal logging and are encouraged to avoid excessive cutting of large trees at managed sites. Although less destructive than clearcutting of tropical forests, unregulated açaí management can still cause considerable losses to the species composition and forest structure of Amazonian forests. For instance, certified managed sites harbor many trees with large diameters (larger than $100-120 \mathrm{~cm}$ of DBH) and heights (30-40 m). According to the relationship between richness/biomass and açaí density described by Freitas et al. (2015), we expected to find low values of açaí density at the certified study sites, especially in those plots with higher basal area. Surprisingly, açaí density between certified and non-certified managed sites was not significantly different. Therefore, certified managed sites can hypothetically maintain fruit production at similar rates to non-certified forests, if the mean fruit production per açaí palm happens to be the same disregarding the abiotic differences among plots.

Recent studies have assessed the ecological outcomes and provided evidence for the positive impacts of certification (Willemen et al. 2019; Furumo et al. 2020, Pico-Mendonza et al. 2020). For instance, certified coffee agroforestry from Costa Rica were less prone to deforestation and provided more ecosystem services than non-certified forests (Pico-Mendonza et al. 2020). Similar findings were shown in Colombia where certified coffee plantations had an increased diversity of shade-trees compared to uncertified farms (Ibanez and Blackman 2016). However, certification also has its limitations (Waldman and Kerr 2014), with complex and expensive processes that often limit small productions (Loconto and Dankers 2014; Brandi et al. 2015). Although certification is not the only avenue to sustainability, it can provide a regulated system to accomplish and detail advancements through identifying indicators and auditing açaí management practices.

In line with our results, we suggest that açaí certification can promote ecologically sound management to supply national and international markets. In addition, with a combined effort to aggregate producer cooperatives, certification provides a platform to better support the livelihoods of açaí producers as they face the growing and changing market.

The future of açaí management certification

Considering the rising market, certification can be a vital mechanism for gaining appreciation and increasing value for açaí superfood products (Hogarth 2004; de Oliveira and Schwartz 2018). In 2016, approximetly 300,000 tons of açaí-based products were sold around the world (Future Market Insights 2017). Also, the açaí global market is projected to exceed 1 million tons in sales and hit nearly 2 billion USD in revenue by the end of 2026 (Future Market Insights 2017). With more than $55 \%$ market share, Latin America will dominate the global sales towards the end of the projected period. 
In Brazil, new opportunities for açaí management certification are emerging (Anderson and Jardim 2019) and $92 \%$ of producers who had heard of certification consider it an advantageous route for reaching a better valuation for their açaí (Pepper and Alves 2017). Several third-party certification programs offered in Pará and Amapá States (e.g. ECOCERT Brasil, IBD Certifications, and IMAFLORA) are mostly directed to large-scale producers or cooperative farmers but these companies have started to extend programs more suitable for smallscale açaí producers (Pepper and Alves 2017; Johnson et al. 2018), offering them an edge in international markets.

Embracing a tactical approach for expanding certification in priority zones in Amazonia should involve collaboration across a number of sectors. Governments and civil society will have to act along with açaí food companies and investors to identify how certification might offer the greatest benefits to biodiversity protection and sustainable livelihoods. Frontiers of expansion for commercial açaí groves could be the focal point for the application of norms to safeguard intact forests.

\begin{abstract}
Authors' contribution GD, MA and PVAF conceived the project. GD, PVAF and ROP performed fieldwork and data collection. GD performed data analysis and led the manuscript writing. FW, RLA, JS and MTFP provided additional data from control plots and revised the manuscript. AA, CDB and PVAF revised and supervised the manuscript writing.
\end{abstract}

Funding Open access funding provided by University of Gothenburg. GD is funded by Vinnova (2019-02717) and Sambazon Inc. Biodiversity Grant. AA ifs funded by the Swedish Research Council, the Swedish Foundation for Strategic Research and the Royal Botanic Gardens, Kew.

Data availability Data will be promptly available under request to the corresponding author.

\section{Declarations}

Conflict of interest The authors declare that they have no conflicts of interest.

Open Access This article is licensed under a Creative Commons Attribution 4.0 International License, which permits use, sharing, adaptation, distribution and reproduction in any medium or format, as long as you give appropriate credit to the original author(s) and the source, provide a link to the Creative Commons licence, and indicate if changes were made. The images or other third party material in this article are included in the article's Creative Commons licence, unless indicated otherwise in a credit line to the material. If material is not included in the article's Creative Commons licence and your intended use is not permitted by statutory regulation or exceeds the permitted use, you will need to obtain permission directly from the copyright holder. To view a copy of this licence, visit http://creativecommons.org/licenses/by/4.0/.

\section{References}

Anderson AB, Jardim MAG (2019) Costs and benefits of floodplain forest management by rural inhabitants in the Amazon estuary: a case study of Açaí palm production. In: Fragile lands of Latin America. Routledge, pp 114-129

Assis RL, Haugaasen T, Schöngart J, Montero JC, Piedade MT, Wittmann F (2015) Patterns of tree diversity and composition in Amazonian floodplain paleo-várzea forest. J Veg Sci 26(2):312-322

Assis RL, Wittmann F, Bredin YK, Schöngart J, Quesada CAN, Piedade MTF, Haugaasen T (2019) Above-ground woody biomass distribution in Amazonian floodplain forests: effects of hydroperiod and substrate properties. For Ecol Manage 432:365-375

Barrett CB (2001) Measuring integration and efficiency in international agricultural markets. Appl Econ Perspect Policy 23(1):19-32

Bezerra LA, Campbell AJ, Brito TF, Menezes C, Maués MM (2020) Pollen loads of flower visitors to açaí palm (Euterpe oleracea) and implications for management of pollination services. Neotrop Entomol 49(4):482-490

Brandi C, Cabani T, Hosang C, Schirmbeck S, Westermann L, Wiese H (2015) Sustainability standards for palm oil: challenges for smallholder certification under the RSPO. J Environ Dev 24(3):292-314

Brando PM, Soares-Filho B, Rodrigues L, Assunção A, Morton D, Tuchschneider D, Fernandes ECM, Macedo MN, Oliveira U, Coe MT (2020) The gathering firestorm in southern Amazonia. Sci Adv 6(2):eaay1632

Brondízio ES (2008) The Amazonian Caboclo and the Açaí palm: forest farmers in the global market. Adv Econ Bot 16:iii-403

Campbell AJ, Carvalheiro LG, Maués MM, Jaffé R, Giannini TC, Freitas MAB, Coelho BWT, Menezes C (2018) Anthropogenic disturbance of tropical forests threatens pollination services to açaí palm in the Amazon river delta. J Appl Ecol 55(4):1725-1736

Freitas MAB, Vieira ICG, Albernaz ALKM, Magalhães JLL, Lees AC (2015) Floristic impoverishment of Amazonian floodplain forests managed for açaí fruit production. For Ecol Manage 351:20-27

Furumo PR, Rueda X, Rodríguez JS, Ramos IKP (2020) Field evidence for positive certification outcomes on oil palm smallholder management practices in Colombia. J Clean Prod 245:118891

Future Market Insights (2017) Acai berry market: global industry analysis and opportunity assessment. Available in: http://www.futuremarketinsights.com/reports/sample/repgb-1207 
Gibbs HK, Ruesch AS, Achard F, Clayton MK, Holmgren P, Ramankutty N, Foley JA (2010) Tropical forests were the primary sources of new agricultural land in the 1980s and 1990s. Proc Nat Acad Sci 107(38):16732-16737

Govindan K (2018) Sustainable consumption and production in the food supply chain: a conceptual framework. Int J Prod Econ 195:419-431

Hogarth P (2004) Site-specific silviculturelecology and silviculture of tropical wetland forests. In: Encyclopedia of forest sciences. Elsevier, pp 1094-1100

Homma AKO, Nogueira OL, de Menezes AJEA, de Carvalho JEU, Nicoli CML, de Matos GB (2006) Açaí: novos desafios e tendências. Embrapa Amazônia Oriental-Artigo em periódico indexado (ALICE)

Ibanez M, Blackman A (2016) Is eco-certification a win-win for developing country agriculture? Organic coffee certification in Colombia. World Dev 82:14-27

Johnson H, Parker C, Maguire R (2018) Consumer choice as a pathway to food diversity: a case study of açaí berry product labelling. In: Food diversity between rights, duties and autonomies. Springer, Cham, pp 307-322

Karney CFF (2013) Algorithms for geodesics. J Geodesy $87: 43-55$

Loconto A, Dankers C (2014) Impact of international voluntary standards on smallholder market participation in developing countries: a review of the literature. Food and Agriculture Organization of the United Nations (FAO)

Lovejoy TE, Nobre C (2018) Amazon tipping point. Sci Adv 4(2):eaat 2340

Matharu M, Jain R, Kamboj S (2020) Understanding the impact of lifestyle on sustainable consumption behavior: a sharing economy perspective. Manage Environ Qual Int J

Oksanen J, Blanchet FG, Friendly M, Kindt R, Legendre P, McGlinn D, Minchin PR, O'Hara RB, Simpson GL, Solymos P, Stevens MHM, Szoecs E, Wagner H (2020) vegan: community ecology package. $\mathrm{R}$ package version $2.5-5$. de Oliveira MDS, Schwartz G (2018) Açaí-Euterpe oleracea. In: Exotic fruits. Academic Press, pp 1-5

Pepper LG, Alves LDFN (2017) Small-scale Açaí in the global market: adding value to ensure sustained income for forest farmers in the Amazon Estuary. In: Integrating landscapes: agroforestry for biodiversity conservation and food sovereignty. Springer, Cham, pp 211-234

Perrigo A, Vrasdonk E, Durkin L, Antonelli A (2020) The full impact of supermarket products. Sustainability Community Springer Nature. https://sustainabilitycommunity. springernature.com/posts/the-full-impact-ofsupermarketproducts. Acessed 26 Oct 2020

Pico-Mendoza J, Pinoargote M, Carrasco B, Limongi Andrade $R$ (2020) Ecosystem services in certified and non-certified coffee agroforestry systems in Costa Rica. Agroecol Sustain Food Syst 1-17

R Core Team (2020) R: a language and environment for statistical computing. R Foundation for Statistical Computing, Vienna, Austria. URL https://www.R-project.org/

Tregidgo D, Campbell AJ, Rivero S, Freitas MAB, Almeida O (2020) Vulnerability of the Açaí palm to climate change. Hum Ecol 48(4):505-514

Waldman KB, Kerr JM (2014) Limitations of certification and supply chain standards for environmental protection in commodity crop production. Ann Rev 6:429-449

Weinstein S, Moegenburg S (2004) Acai palm management in the Amazon Estuary: course for conservation or passage to plantations? Conserv Soc 315-346

Willemen L, Crossman ND, Newsom D, Hughell D, Hunink JE, Milder JC (2019) Aggregate effects on ecosystem services from certification of tea farming in the Upper Tana River basin, Kenya. Ecosyst Serv 38:100962

Publisher's Note Springer Nature remains neutral with regard to jurisdictional claims in published maps and institutional affiliations. 